\title{
Review of Alexandra Xanthaki, Sanna Valkonen, Leena Heinämäki \& Piia Nuorgam (eds.), Indigenous Peoples' Cultural Heritage - Rights, Debates, Challenges
}

\section{Stefan Kirchner*}

Associate Professor of Arctic Law, Arctic Centre, University of Lapland, Rovaniemi, Finland

Alexandra Xanthaki, Sanna Valkonen, Leena Heinämäki \& Piia Nuorgam (eds.), Indigenous Peoples' Cultural Heritage - Rights, Debates, Challenges. Brill Nijhoff, Leiden and Boston. 2017. 351 pages, ISBN 9789004342187.

Indigenous culture is often appropriated by outsiders. From music to dress, traditional items to essential livelihoods, from art to valuable knowledge about the healing properties of plants, ${ }^{1}$ the tangible and intangible intellectual property of indigenous peoples is at risk. This is particularly the case when it comes to the cultural heritage of indigenous communities, for example in the context of advertising for travel and tourism or other commercial services. ${ }^{2}$ The collection of fifteen essays reviewed here provides more than just an introduction to the topic. The book manages to make the concept of cultural heritage accessible for lawyers and provides indigenous actors with valuable information for the protection of indigenous rights.

International human rights law is the starting point for the book. The authors do not stop at outlining the existing legal norms but look at potential future developments and, maybe most importantly, show how international law can be made practically fruitful for the protection of indigenous cultural heritage. There is a clear focus on international human rights law, in particular in relation to indigenous rights and classical questions of indigenous rights law, such as self-determination and self-governance - but the authors also provide connections to more general issues of public international law, such as the abandonment of the terra nullius concept, which is examined both in the context of human rights law as well as in the context of the situation in South Africa. In addition, participatory rights and general human

`Correspondence to: stefan.kirchner@ulapland.fi 


\section{Stefan Kirchner}

rights law, such as property rights, are taken into account. From the perspective of international human rights law, the book provides a complete picture and a solid introduction to problems surrounding indigenous cultural heritage.

The inclusion of authors who are experts on cultural heritage law rather than indigenous rights also guarantees a holistic approach. In addition, the book exhibits a particular regional approach, with one chapter on the recognition of Sámi land rights in Norway and another on the co-managed Laponia UNESCO World Heritage Site. Land rights and their importance for the cultural rights of indigenous communities are not to be underestimated. Often, land use conflicts are at the core of conflicts between indigenous and non-indigenous communities. Increasing respect for indigenous communities requires respect for the legal traditions of indigenous communities, not only from a legal anthropological perspective, but also through an acceptance of indigenous law not only as an expression of society but as actual law, on par with other legal systems. While indigenous customary law has been recognized in some cases, ${ }^{3}$ this is the exception rather than the norm. The loss of indigenous legal regimes and sovereignty is illustrated with an example from Finland concerning the abolishment of the traditional Sámi siida reindeer herding system, which the State replaced with reindeer herding cooperatives which also include non-indigenous members.

Finally, restitution and reparations, issues often seen as politically problematic in the context of indigenous rights but which have a basis in international human rights law, are discussed.

Due to centuries of oppression, restitution remains a difficult subject - but this does not mean that discussions about this issue are impossible. This book also shows ways to approach issues of reparation and restitution from a legal perspective in an attempt to contribute to the pursuit of justice.

The volume brings together authors from different academic backgrounds, including a significant number of indigenous authors from different countries, mainly from Europe and North America. In addition to academic experts on indigenous rights, the authors also include practitioners, such as Willa Boezak, who advises a number of indigenous entities in South Africa, or the former Vice President of the Inuit Circumpolar Council, Violet Ford. The choice of authors, which contains leading experts of international renown as well as emerging voices in the field, reflects not only the importance of legal research for the protection of intellectual property rights but also the need for a multidisciplinary approach. In particular, readers from Northern Europe will find that the book covers many issues of current interest. Cases from other parts of the world, however, also receive attention when the existing body of case law on indigenous cultural heritage rights is available in English.

The book mainly takes a legal perspective, but readers from other disciplines should also find it of interest. Overall, the authors provide a comprehensive picture of indigenous cultural heritage law and its connections to indigenous rights law, human rights and international law. The book is likely to appeal to a wide readership 
for years to come. Thanks to the choice of topics, readers interested in cultural heritage will find the book as engaging as readers involved with indigenous issues. Because of its strong focus on the indigenous peoples of the Arctic and Sub-Arctic, the book will be of particular relevance to researchers, students and practitioners in the political and social sciences from this region, even though it is first and foremost a legal book.

\section{Notes}

1. See e.g. Tobias Lochen, Die völkerrechtlichen Regelungen über den Zugang zu genetischen Ressourcen, Mohr Siebeck, Tübingen (2007), pp. 41 et seq.

2. Cf. William M. O'Barr, "Images of Native Americans in Advertising”, in: 14 Advertising and Society Review (2013), pp. 1-51.

3 For examples from Norway see Øyvind Ravna, "The legal Protection of the Rights and Culture of Indigenous Sámi People in Norway”, in: 11 fournal of Siberian Federal University. Humanities E Social Sciences (2013), pp. 1575-1591, at pp. 1587 et seq. 